\title{
Siegel für Nachhaltigkeit
}

Neben den Bio-Logos gibt es noch mehr Logos für nachhaltiges Essen.

Nachhaltig bedeutet, dass man mit der Umwelt verantwortungsvoll umgeht. Nachhaltig bedeutet, dass man die Natur nicht ausbeutet.

\section{MSC-Logo}

Das MSC-Logo ist ein Zeichen

für nachhaltigen Fisch•fang. Bedrohte Bei nachhaltigem Fisch •fang wird nur eine bestimmte Menge Fische gefangen. So bleiben genug Fische im Meer, damit neue Fische nachwachsen können. Bedrohte Arten werden nicht gefangen. Man findet es inzwischen auf vielen Fisch-Produkten im Super•markt.

\section{Fairer Handel}

Fairer Handel bedeutet, dass die Bauern in armen Ländern nicht ausgebeutet werden.

Kaffee wird zum Beispiel in Süd•amerika oder Afrika angebaut. Große Firmen zahlen den Bauern dort oft nur wenig Geld. Das Geld reicht oft nicht zum überleben.

Firmen wie Fairtrade oder UTZ haben

Regeln, dass die Bauern anständig bezahlt werden.

\section{Dafür gibt es verschiedene Logos:}

Das Fairtrade-Logo oder das UTZ-Logo für Kaffee oder Schokolade sieht man oft im Super•markt.
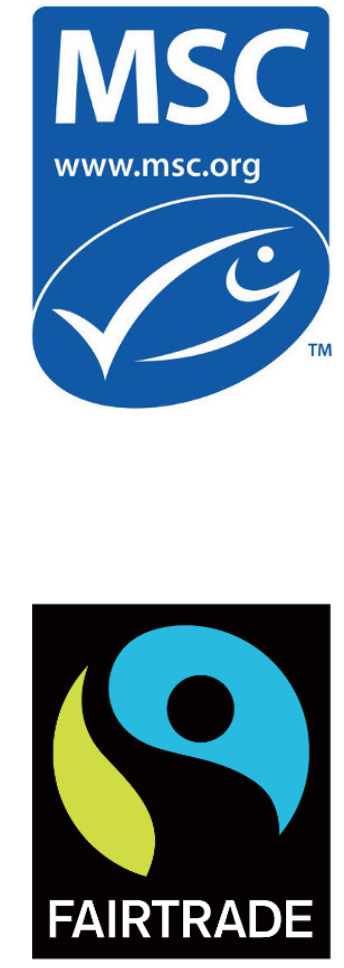

(R)

Das Siegel für Fairen Handel

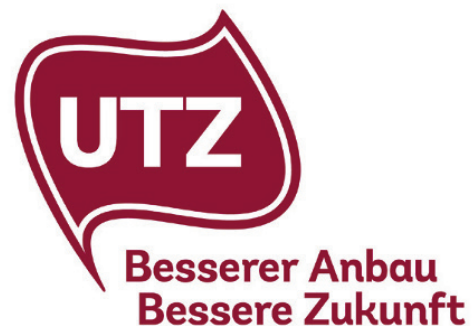

